\title{
Prevalence of gastro-intestinal symptoms during pregnancy: a questionnaire based study in a tertiary care center of South Asia
}

\section{J. B. Sharma, Debjyoti Karmakar*, Shena Aggarwal, Saurabh Singhal, K. K. Roy, S. Kumar}

Department of Obstetrics and Gynecology, All India Institute of Medical Sciences, New Delhi-110029, India

Received: 4 December 2013

Accepted: 15 December 2013

\author{
*Correspondence: \\ Dr. Debjyoti Karmakar, \\ E-mail: dkcoolmed@yahoo.com
}

(C) 2014 Sharma JB et al. This is an open-access article distributed under the terms of the Creative Commons Attribution Non-Commercial License, which permits unrestricted non-commercial use, distribution, and reproduction in any medium, provided the original work is properly cited.

\begin{abstract}
Background: Gastrointestinal symptoms lead to morbidity in pregnancy, yet remain a surprisingly under-researched topic. The objective was to find out the prevalence of various gastro-intestinal symptoms in pregnant women, the status before pregnancy, and their perceived impact.

Methods: A questionnaire incorporating various gastro-intestinal problems was prepared and used over 184 pregnant women to know their prevalence in different trimesters of pregnancy and compare them with prevalence before pregnancy. 184 matched non-pregnant women were also interrogated as additional control group.

Results: Constipation was seen significantly more often during pregnancy $(24.5 \%)$ and was maximum in the first trimester $(31.8 \%)$ followed by third trimester $(26.3 \%)$ and second trimester $(19.0 \%)$ as compared to only $9.8 \%$ of women in non-pregnant state. Diarrhea was also more rampant in pregnancy $(9.2 \%)$, especially in third trimester $(13.1 \%)$ than before pregnancy $(1.6 \%)$. Constipation, diarrhea and fecal incontinence were much commoner in pregnant as compared to non-pregnant controls.

Conclusions: There is a very high prevalence of gastro-intestinal symptoms during pregnancy as compared to nonpregnant state. More studies are needed to highlight the Quality-Of-Life issues with these symptoms.
\end{abstract}

Keywords: Pregnancy, Gastro-intestinal system, Constipation, Diarrhea, Questionnaire

\section{INTRODUCTION}

Fecal and urinary incontinence can have a devastating effect on a woman's quality of life. ${ }^{1}$ Although vaginal delivery has been implicated as a predisposing factor, pregnancy itself is a high risk factor as there is a high prevalence of postpartum fecal incontinence independent of parity, suggesting an individual predisposition to pelvic floor weakness and subsequent incontinence. ${ }^{1-3}$ Increased joint mobility indicating systemic alterations in collagen during pregnancy may be responsible for the same. $^{4-9}$ Chaliha et al. ${ }^{3}$ found a prevalence of fecal incontinence before, during and after pregnancy as 3.6\%, $43.7 \%$ and $14.6 \%$ respectively, with fecal urgency being more common after spontaneous vaginal and instrumental deliveries as compared to caesarean sections; a finding observed by other authors too. ${ }^{10,11}$
Various other gastro-intestinal complaints are seen to occur frequently during pregnancy, for example constipation is common in pregnancy due to the effect of progesterone, which causes relaxation of smooth muscles of gastro-intestinal tract. Diarrhea may be due to intestinal infections, which are common in developing countries like India. ${ }^{12-16}$

The present study was a questionnaire based study conducted to find out the prevalence of various gastrointestinal complaints during and before pregnancy as the data regarding the same is very scarce in South Asian countries like India. Determining the prevalence of problematic symptoms could prove useful in deciding the need of improved screening procedures and treatment modalities. 


\section{METHODS}

This study is part of our larger study on the prevalence of urogynaecological /gastrointestinal problems in obstetric and gynecological practice approved by the ethical committee of the hospital. A total of 184 women attending the antenatal clinic of our unit were interrogated from January 2008 to July 2009 regarding various gastro-intestinal symptoms (like normal bowel habits, diarrhea, constipation and fecal incontinence) during pregnancy as per the designed questionnaire (Appendix 1). Consent was taken for inclusion in this study. The questionnaire was applied by interviewing the pregnant women in both English for English speaking or understanding women and in regional language for illiterate and less literate participants. The responses of illiterate patients were noted down by staff nurse in the presence of interviewer.

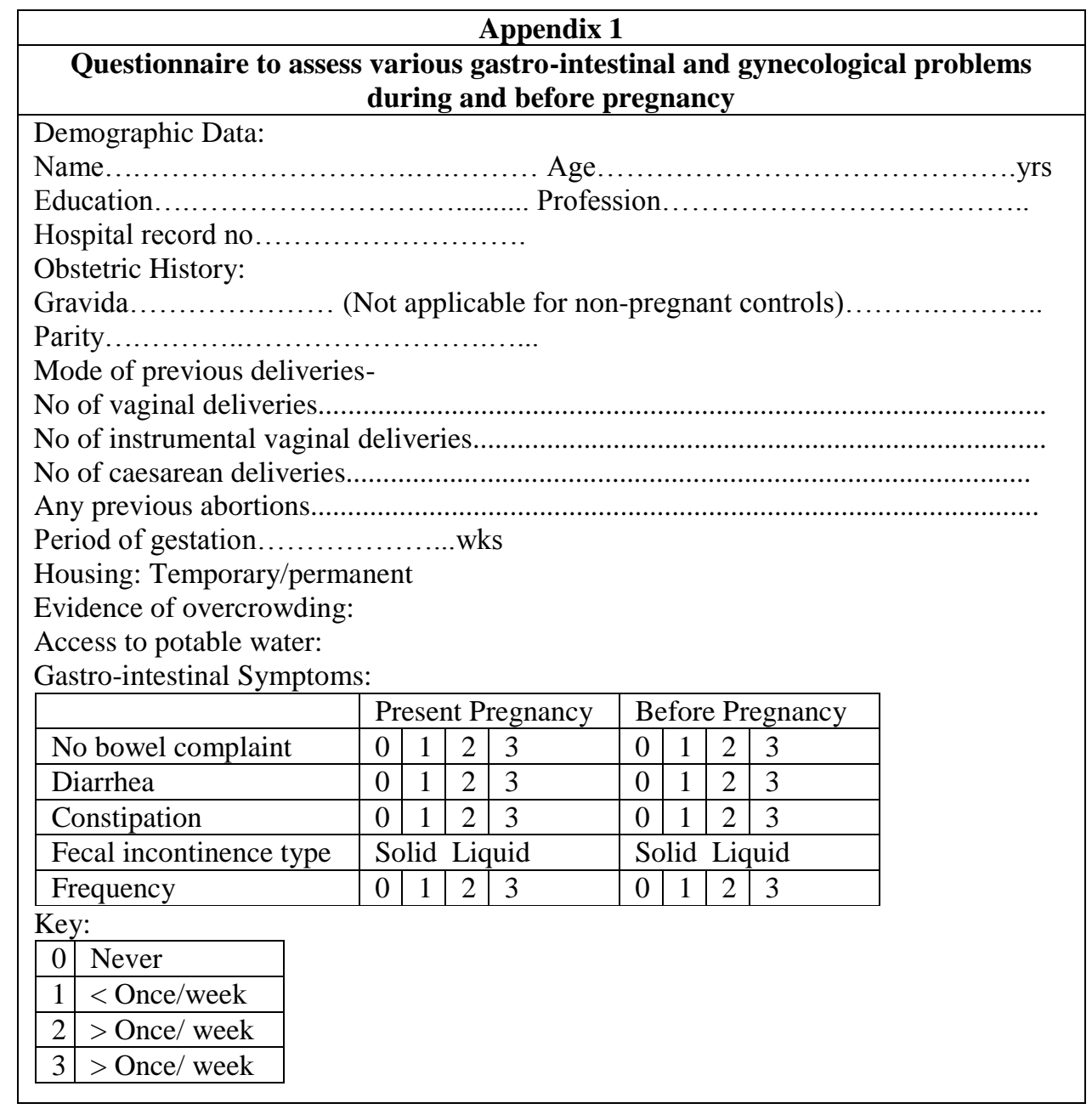

The various questions asked were about bowel habits, number of times the women passed motions in a week, any constipation, diarrhea and any fecal incontinence (included incontinence of liquid and solid stool and soiling of underwear) among gastro-intestinal symptoms. Surroundings have a major influence on water and food borne diseases of gastrointestinal tract; enquiry was made about housing type (permanent/temporary), access to potable water, overcrowded inhabitation. The nonpregnant control group was matched to eliminate these confounding factors. As They were enquired about the occurrence of these complaints both during present pregnancy and before pregnancy [group B, as first control group],to compare the differences in the same patient arising out of pregnancy, to eliminate any confounding factor skewing the results. The frequency of gastrointestinal complaints was correlated with gestation of pregnancy to see if there was any significant difference in the prevalence of these problems during different trimesters of pregnancy. 184 controls matched with the pregnant participants in terms of age, parity, education, profession (and housing, overcrowded surroundings and access to potable water as far as practicable) were chosen as second control group C] to ascertain with confidence the differences in symptomatology in pregnant versus non-pregnant women. This control group was 
incorporated as recall of symptoms of pregnant women during non-pregnant state may be inaccurate.

Statistical analysis was performed using Statistical Package for Social Sciences 15.0 (SPSS Inc.) using Student's T test, Chi square test and Fisher exact test taking $\mathrm{p}$ value $<0.05$ as significant.

\section{RESULTS}

The demographic profile and general information of the respondents is shown in Table 1 . The age ranged from 18 to 39 years with the mean age being 26.4 years. Most women $(70.6 \%)$ were from 20-29 years of age and majority $(79.3 \%)$ were housewives, with majority being illiterate or having less than higher secondary education $(66.3 \%)$. Most of the women $(53.8 \%)$ were in the third trimester of pregnancy while $34.2 \%$ were in second trimester and only $12.0 \%$ were in the first trimester.

Table 1: Demographic characteristics of study and control groups.

\begin{tabular}{|c|c|c|c|}
\hline Characteristic & Category & $\begin{array}{l}\text { No. of pregnant } \\
\text { women }(\mathrm{N}=184) \\
{[\mathrm{A}](\%)}\end{array}$ & $\begin{array}{l}\text { Non-pregnant } \\
\text { matched controls } \\
(\mathrm{N}=184)[\mathrm{C}](\%)\end{array}$ \\
\hline \multirow{5}{*}{$\begin{array}{l}\text { Age }(\text { Years }) \\
{[\text { Range }=18-} \\
39 \text { years, } \\
\text { Mean }=26.4 \\
\text { years }]\end{array}$} & $<20$ & $1(0.5 \%)$ & $1(0.5)$ \\
\hline & $20-24$ & $72(39.2 \%)$ & $73(39.67 \%)$ \\
\hline & $25-29$ & $70(38.0 \%)$ & $71(38.56 \%)$ \\
\hline & $30-34$ & $30(16.3 \%)$ & $29(15.76 \%)$ \\
\hline & $\geq 35$ & $11(6 \%)$ & $10(5.43 \%)$ \\
\hline \multirow{6}{*}{ Education } & Illiterate & $22(12.0 \%)$ & $21(11.41 \%)$ \\
\hline & Primary school & $25(13.6 \%)$ & $24(13.04 \%)$ \\
\hline & Middle level & $35(19.0 \%)$ & $36(19.56 \%)$ \\
\hline & Higher secondary & $40(21.7 \%)$ & $41(22.28 \%)$ \\
\hline & Graduate & $40(21.7 \%)$ & $42(22.82 \%)$ \\
\hline & Postgraduate & $22(12.0 \%)$ & $20(10.87 \%)$ \\
\hline \multirow{2}{*}{ Profession } & House wife & $146(79.3 \%)$ & $144(78.26 \%)$ \\
\hline & Working & $38(20.7 \%)$ & $40(21.74 \%)$ \\
\hline \multirow{3}{*}{ Trimester } & First & $22(12.0 \%)$ & $21(11.41 \%)$ \\
\hline & Second & $63(34.2 \%)$ & $64(34.78 \%)$ \\
\hline & Third & $99(53.8 \%)$ & $99(53.8 \%)$ \\
\hline \multirow{3}{*}{$\begin{array}{l}\text { Parity } \\
{[\text { Range }=0-8,} \\
\text { Mean = 1.6] }\end{array}$} & 0 & $56(30.4 \%)$ & $55(29.89 \%)$ \\
\hline & $1-3$ & $108(58.7 \%)$ & $106(57.61 \%)$ \\
\hline & $4-8$ & $20(10.9 \%)$ & $23(12.5 \%)$ \\
\hline \multirow[t]{4}{*}{ Housing } & Temporary & $18(9.78 \%)$ & $16(8.69 \%)$ \\
\hline & Permanent & $166(90.22 \%)$ & $168(91.30 \%)$ \\
\hline & Overcrowding & $45(24.46 \%)$ & $134(72.82 \%)$ \\
\hline & $\begin{array}{l}\text { Access to potable } \\
\text { water }\end{array}$ & $139(75.54 \%)$ & $134(72.82 \%)$ \\
\hline
\end{tabular}

The prevalence of various gastro-intestinal symptoms in women during and before pregnancy and amongst nonpregnant controls is shown in Table 2. As is clear from the Table, all the gastro-intestinal complaints were significantly more common during pregnancy. $30.4 \%$ of the respondents report one or the other bowel problem during pregnancy as compared to only $10.9 \%$ before it. Constipation was the most common symptom (seen in 45 women, that is $24.5 \%$ ) with prevalence being highest in the first trimester $(31.8 \%)$ followed by third trimester $(26.3 \%)$ and second trimester $(19.0 \%)$ as compared to
$9.8 \%$ in non-pregnant state ( $\mathrm{p}$ value <0.001). Even diarrhea was more common during pregnancy $(9.2 \%)$ than prior to pregnancy $(1.6 \%)$ and was especially common in third trimester $(13.1 \%)$ followed by second trimester $(6.3 \%)$, p value being 0.001 . Fecal incontinence was rare, as it was seen in only one woman in the second trimester of pregnancy and none of the women reporting it before pregnancy. Similar differences were seen in symptomatology of pregnant and non-pregnant controls (Table 2). 
Table 2: Prevalence of gastro-intestinal symptoms during and before pregnancy.

\begin{tabular}{|c|c|c|c|c|c|c|}
\hline Symptom & $\begin{array}{l}\text { During } \\
\text { pregnancy } \\
(n=184)[A]\end{array}$ & $\begin{array}{l}\text { First } \\
\text { trimester } \\
(\mathbf{n}=\mathbf{2 2})\end{array}$ & $\begin{array}{l}\text { Second } \\
\text { trimester } \\
(\mathbf{n}=\mathbf{6 3})\end{array}$ & $\begin{array}{l}\text { Third } \\
\text { trimester } \\
(\mathbf{n}=99)\end{array}$ & $\begin{array}{l}\text { Before } \\
\text { pregnancy } \\
\text { (Recall) } \\
(\mathrm{n}=184)[\mathrm{B}]\end{array}$ & $\begin{array}{l}\text { Non-pregnant } \\
\text { matched } \\
\text { controls } \\
(\mathrm{n}=\mathbf{1 8 4})[\mathrm{C}]\end{array}$ \\
\hline Normal bowel habits & $128(69.6 \%)$ & $15(68.2 \%)$ & $49(77.8 \%)$ & $64(64.6 \%)$ & $164(89.1 \%)$ & $159(86.41 \%)$ \\
\hline Diarrhea & $17(9.2 \%)$ & $0(0.0 \%)$ & $4(6.3 \%)$ & $13(13.1 \%)$ & $3(1.6 \%)$ & $6(3.26 \%)$ \\
\hline Constipation & $45(24.5 \%)$ & $7(31.8 \%)$ & $12(19.0 \%)$ & $26(26.3 \%)$ & $18(9.8 \%)$ & $19(10.33 \%)$ \\
\hline Fecal incontinence & $1(0.5 \%)$ & $0(0.0 \%)$ & $1(1.6 \%)$ & $0(0.0 \%)$ & $0(0.0 \%)$ & $\%)$ \\
\hline \multicolumn{7}{|c|}{$\begin{array}{l}\text { P values } \\
\text { - } \quad \text { Diarrhea before and during pregnancy - } 0.001 \text { (highly significant) } \\
\text { - } \quad \text { Constipation before and during pregnancy - } 0.000 \text { (highly significant) } \\
\text { - } \quad \text { Fecal incontinence before and during pregnancy - } 0.317 \text { (not significant) } \\
\text { - } \quad \text { Diarrhea during pregnancy and non-pregnant controls - } 0.001 \text { (highly significant) } \\
\text { - } \quad \text { Constipation during pregnancy and non-pregnant controls - } 0.001 \text { (highly significant) } \\
\text { - } \quad \text { Fecal incontinence during pregnancy and non-pregnant controls - } 0.402 \text { (not significant) } \\
\text { - } \quad \text { Diarrhea in different trimesters - } 0.098 \text { (not significant) } \\
\text { - } \quad \text { Constipation in different trimesters - } 0.403 \text { (not significant) } \\
\text { - } \quad \text { Fecal incontinence in different trimesters - 0.381 (not significant) }\end{array}$} \\
\hline
\end{tabular}

Note- Many patients had more than one complaint

\section{DISCUSSION}

The present study confirms a higher frequency of lower gastro-intestinal symptoms during pregnancy with constipation being the most common symptom $(24.5 \%)$ as compared to $9.8 \%$ in non-pregnant state. It is followed by diarrhea which is present in $9.2 \%$ women during pregnancy in contrast to $1.6 \%$ women before pregnancy. None of these women complained voluntarily or sought medical help for the same, which is not surprising as these symptoms are frequently known to be underreported, ${ }^{2}$ especially in a country like India. Previous studies have reported a high prevalence of fecal incontinence related to pregnancy and child birth. ${ }^{1-3}$ Chaliha et al. $^{3}$ reported prevalence of fecal incontinence as $0.7 \%, 6.0 \%$ and $5.5 \%$ before, during and after pregnancy respectively. Vaginal delivery has been implicated as a predisposing factor and this is one of the important reasons for the increased demand for caesarean deliveries to protect pelvic floor function. However the higher incidence of symptoms during pregnancy, as in our study, also suggests an individual predisposition to pelvic floor weakness and subsequent urinary and fecal incontinence. $^{3}$ Collagen abnormalities have been associated with increased joint mobility, prolapse and urinary incontinence, ${ }^{4-6}$ yet their relation to fecal incontinence is not fully understood. ${ }^{7-9}$ Increased joint mobility probably indicates systemic alterations in collagen during pregnancy. Vaginal delivery causes anal sphincter disruption, with occult and sphincter trauma being more following randomized forceps and vacuum delivery. ${ }^{10,11}$ This, however, should not prompt elective caesarean section to prevent fecal incontinence, as women can have the fore-mentioned symptoms even during pregnancy and after caesarean deliveries due to changes occurring during pregnancy.

Our study concentrated on the situation during pregnancy and observed a high prevalence of constipation and diarrhea during pregnancy. Pregnancy itself doesn't cause diarrhea; it is often caused by same disorders as in nonpregnant state, but it could be due to increased rate of gastro-intestinal infections (like parasitic or bacterial infections) which are widespread in India. Constipation is often the result of physiological changes occurring during pregnancy, resulting from hormonal influences on gastrointestinal motility. Even intake of iron tablets, which is almost universal in India, can cause constipation as well as diarrhea and may even be responsible for some of the cases seen in the present study; a fact which might have skewed the observations in this study compared to populations in western countries.

Various questionnaires have been developed to obtain useful information in Obstetrics and Gynecology and each must be customized to suit the sensibilities of the study population and special requirements of the researchers in a particular region. ${ }^{17-21}$ We do realize that absence of a Quality-of-Life survey of these patients has weakened the conclusions by failing to highlight significant morbidity in terms of quality of life. However as this was a clinic based survey, incorporating Qualityof-Life survey would have made the questionnaire cumbersome and the study difficult to carry out. However these results can be used to plan newer questionnaire to assess the morbidity because of such common symptoms which often remain underreported. 


\section{CONCLUSIONS}

Our study confirms the high burden of various gastrointestinal problems in Indian setting and emphasizes the need of active surveillance and comprehensive approach for prevention and control strategies targeting the specific gastro-intestinal and gynecological problems causing significant bother and worsening of the quality of life in pregnant women.

\section{Funding: No funding sources}

Conflict of interest: None declared

Ethical approval: The study was approved by the hospital ethics committee

\section{REFERENCES}

1. MacArthur C, Bick DE, Keighley MRB. Faecal incontinence after childbirth. Br J Obstet Gynaecol. 1997;104:46-50.

2. Leigh RJ, Turnberg LA. Faecal incontinence: The unvoiced symptom. Lancet.1982;1(8285):1349-51.

3. Chaliha C, Kalia V, Stanton SL et al. Antenatal prediction of postpartum urinary and fecal incontinence. Obstet Gynecol. 1999;94:689-94.

4. Burgeson R. Genetic heterogeneity of collagens. J Invest Dermatol. 1982;79:25-30.

5. Ulmsten U, Ekman G, Giertz G, Malmstrom A. Different biochemical composition of connective tissue in continent and stress incontinent women. Acta Obstet Gynecol Scand. 1987;66:455-7.

6. Norton PA. Pelvic floor disorders: The role of fascia and ligaments. Clin Obstet Gynecol. 1993;36:92638.

7. Parks AG, Swash M, Urich H. Sphincter denervation in anorectal incontinence and rectal prolapse. Gut. 1977; 18:656-65.

8. Beersiek F, Parks AG, Swash AM. Pathogenesis of anorectal incontinence: A histometric study of anal sphincter musculature. J Neurol Sci. 1979;42:111-27.

9. Calguneri M, Bird HA, Wright V. Changes in joint laxity occurring during pregnancy. Ann Rheum Dis 1982;41:126-8.

10. Sultan AH, Kamm MA, Hudson CN, Thomas JM, Bartram CI. Anal sphincter disruption during vaginal delivery. N Engl J Med. 1993;329:1905-11.

11. Sultan AH, Johansen RB, Carter JE. Occult and sphincter trauma following randomized forceps and vacuum delivery. Int $\mathbf{J}$ Gynaecol Obstet. 1998;61:113-9.

12. Stanley VC, Jones JB, Hurley R, Foulkes JEB, Louvois J. Morbidity of the lower genital tract during pregnancy. J Clin Path. 1975;28:736-40.

13. Hakakha MM, Davis J, Korst LM, Silverman NS. Leukorrhea and Bacterial Vaginosis as In-Office Predictors of Cervical Infection in High-Risk Women. Obstet Gynecol. 2002;100:808-12.

14. McGregor JA, French JI. Bacterial vaginosis in pregnancy. Obstet Gynecol Surv. 2000;55:1-19.

15. Eschenbach DA, Hillier S, Critchlow C, Stevens C, De-Rousen T, Holmes KK. Diagnosis and clinical manifestations of bacterial vaginosis. Am J Obstet Gynecol. 1988;158:819-28.

16. Division of STD prevention. Sexually transmitted disease surveillance, Atlanta, GA: Centers for Disease Control and Prevention. 1998-1999. Available at: http://www.cdc.gov/std/stats08/surv2008complete.pdf. Accessed November 2009.

17. Sharma JB, Malhotra M, Gupta S, Kumar A, Singh BP, Vindal A. A preliminary survey of patients views on awareness, information choices and expectations in women undergoing hysterectomy. J Ind Med Assoc. 2004;102:304-8.

18. Sharma JB, Malhotra M, Joshi D, Arora R. Survey of the patients' views on awareness, information, choices and care during labor in a teaching hospital. J Obstet Gynecol India. 2003;53:252-6.

19. Sharma JB, Sharma K, Sarin U. A study of maternal awareness and participation during caesarean section. J Obstet Gynecol India. 2001;51:37-9.

20. Sharma JB, Gupta N, Aggarwal P, Mittal S. A survey of obstetricians' practice of using prophylactic antibiotics in vaginal deliveries and caesarean sections. J Indian Med Assoc. 2008;106:147-9.

21. Sharma JB, Aggarwal S, Singhal S, Kumar S, Roy KK. Prevalence of Urinary incontinence and other urological problems during pregnancy: a questionnaire based study. Arch Gynecol Obstet. 2009 Jun;279(6):845-51.

DOI: $10.5455 / 2320-1770$. ijrcog20140317

Cite this article as: Sharma JB, Karmakar D,

Aggarwal S, Singhal S, Roy KK, Kumar S.

Prevalence of gastro-intestinal symptoms during pregnancy: a questionnaire based study in a tertiary care center of South Asia. Int J Reprod Contracept Obstet Gynecol 2014;3:87-91. 